\title{
KERJASAMA ANTAR DAERAH DALAM PENGEMBANGAN PARIWISATA KAWASAN SANGIRAN
}

\author{
Oennitya Fita Dewi Aryanti ${ }^{1}$, Kristina Setyowati ${ }^{2}$ \\ Program Studi Ilmu Administrasi Negara \\ Fakultas Ilmu Sosial dan Ilmu Politik Universitas Sebelas Maret Surakarta \\ oennityafitadewiaryanti@gmail.com
}

\begin{abstract}
Sangiran area which is located on the border cannot be separated from the problem of sectoral ego so that analysis is carried out using 5 elements of IGR Wright. This study aims to find out the fabric of inter-regional cooperation in tourism development in Sangiran Region and find out the driving and inhibiting factors. The research method uses descriptive qualitative. The data uses primary and secondary data. Data collection uses interviews and documentations. Data analysis uses interactive models. The results of the study explain that there is a division of roles between parties involved in cooperation. Interactions between public officials appear to be similarities in the behavior, beliefs, perceptions and preferansi. Sustainibility communication maintained regulary. Executive and legislative officials play a role in the implementation of cooperation and there is clarity on the role of the designated administrator. Whereas in the policy focus, the budget capacity to carry out cooperation comes from each party and the central government policy is followed up by the local government. The driving factor for collaboration is the existence of common thought, the existence of economic benefits and the support of regional leaders. Inhibiting factors are limited funds. This study implies the addition the role of local governments as dinamisator, the use the allocation of funds village for tourism development programs and local governments together with the community more utilizing the potential of culture.
\end{abstract}

\section{Keyword: decentralization, intergovernmental relations, tourism development}

Abstrak. Kawasan Sangiran yang letaknya di perbatasan tidak terlepas dari pemasalahan ego sektoral sehingga dilakukan analisis dengan menggunakan 5 elemen IGR Wright. Penelitian ini bertujuan untuk mengetahui jalinan kerjasama antar daerah dalam pengembangan pariwisata Kawasan Sangiran dan mengetahui faktor pendorong dan penghambatnya. Metode penelitian menggunakan kualitatif deskriptif. Data yang digunakan adalah primer dan data sekunder. Teknik pengumpulan data menggunakan wawancara dan dokumentasi. Analisis data menggunakan model interaktif. Hasil penelitian menjelaskan bahwa ada pembagian peran antara pihak yang terlibat dalam kerjasama. Interaksi antar pejabat publik nampak kesamaan dalam aspek perilaku, kepercayaan, persepsi dan preferansi. Komunikasi berkelanjutan yang dijalin secara rutin. Pejabat eksekutif dan legislatif turut berperan dalam pelaksanaan kerjasama serta sudah ada kejelasanan peran administrator yang ditunjuk. Sedangkan dalam fokus kebijakan, kapasitas anggaran untuk melaksanakan kerjasama bersumber dari masing-masing pihak dan kebijakan pemerintah pusat ditindaklanjuti oleh pemerintah daerah. Faktor pendorong kerjasama adalah adanya kesamaan pemikiran, adanya keuntungan ekonomi dan dukungan pemimpin daerah. Faktor penghambat yaitu keterbatasan dana. Penelitian ini berimplikasi pada penambahan peran pemerintah daerah sebagai dinamisator, penggunaan alokasi dana desa bagi desa untuk program pengembangan pariwisata dan pemerintah daerah bersama masyarakat lebih memanfaatkan potensi budaya.

Kata kunci : desentralisasi, kerjasama antar daerah, pengembangan pariwisata 


\section{PENDAHULAN}

Pariwisata merupakan salah satu sektor yang mempunyai peran strategis dalam perkembangan perekonomian di Indonesia. Menurut Suwantoro (2004:3536), "sektor pariwisata apabila dilihat dari aspek ekonomi pariwisata, sektor ini diharapkan menjadi penghasilan devisa utama dan sarana untuk mengurangi penganguran sehingga pariwisata mampu berkontribusi dalam pembangunan suatu wilayah".

Besarnya sumbangan dari sektor pariwisata seperti penghasil devisa negara dan sektor yang mampu membuka lapangan pekerjaan maka pariwisata harus mendapatkan perhatian khusus pemerintah untuk dikembangkan. Pengembangan pariwisata tidak hanya dilakukan pemerintah pusat. Kebijakan pemerintah daerah dalam pengembangan pariwisata sangat penting perananya dalam menunjang keberhasilan pengembangan pariwisata nasional. Perkembangan dan pertumbuhan pariwisata perlu diantisipasi agar perkembanganya tetap pada jalurnya dan daya dukunganya. Pengembangan dalam wilayah objek wisata akan memberikan sumbangan yang sangat besar apabila dikelola secara profesional, karena sumbangan bagi daerah yang bersangkutan, pariwisata dapat memacu pertumbuhan kawasan sekitar objek wisata tersebut (Simamora dan Sinaga, 2016).

Pengembangan pariwisata akan terjadi saling ketergantungan antara daerah yang satu dengan daerah yang lain dan dengan pelaksanaan Undang-Undang Nomor 23 Tahun 2014 tentang Pemerintahan Daerah diyakini akan mendorong daerah untuk lebih bersikap mandiri karena memiliki kewenangan untuk mengurus dan mengontrol daerahnya sendiri. Kemandirian tersebut, bisa menciptakan pertumbuhan ekonomi lebih baik, termasuk pengelolaan pariwisata daerah (Wahyudi, 2010).

Adanya Undang-Undang 23 Tahun 2014 tentang Pemerintahan Daerah, juga memberikan kesempatan kepada kabupaten/kota untuk melakukan kerja sama dengan kabupaten/kota, provinsi dan pusat. Kenyataannya tidak semua sumber daya yang dibutuhkan daerah di dalam membangun atau menyelenggarakan pelayanan publik dimiliki oleh daerah, oleh karena itu daerah memerlukan daerah lain untuk menghasilkan sesuatu yang diinginkannya. Adanya keterbatasan anggaran belanja publik dalam suatu daerah sehingga apabila daerah satu dengan daerah yang lain memiliki tujuan yang sama maka kerja sama merupakan jawaban untuk efisiensi terhadap penggunaan anggaran daerah. Hal-hal tersebut menjadikan daerah-daerah yang bersangkutan merasa perlu untuk melakukan koordinasi dan kerja sama dalam pelaksanaan dan upaya pencapaian beberapa keinginan daerah yang muncul tersebut.

Usaha pemerintah untuk mengembangkan pariwisata Indonesia adalah salah satunya dengan menetapkan Peraturan Pemerintah Nomor 50 Tahun 2011 tentang Rencana Induk Pembangunan Kepariwisataan Nasional (RIPPNAS). Dalam kebijakan terdapat kategori daya tarik wisata yang terdiri dari Destinasi Pariwisata Nasional dan Kawasan Strategis Pariwisata Nasional. Salah satunya adalah Kawasan Sangiran.

Kawasan Sangiran sendiri berada di wilayah perbatasan. Kawasan Sangiran sebagian besar masuk dalam Kecamatan 
Kalijambe, Kecamatan Gemolong dan Kecamatan Plupuh yang berada di Kabupaten Sragen. Sebagian lagi masuk dalam kecamatan Gondangrejo di Kabupaten Karangnyar. Sebagai salah satu warisan budaya nasional dan dunia yang letaknya di daerah, maka dalam pengembangan pariwisata dilakukan dengan menjalin kerjasama antara pemerintah pusat dan pemerintah daerah. Kerjasama antar daerah pun telah dijalin pemerintah pusat dan pemerintah daerah.

Namun, sebagai kawasan di perbatasan suatu wilayah tidak terlepas dari adanya ego sekoral. Nurhan dan Sulistyanto (2009) mengungkapkan bahwa "Kabupaten Sragen telah membangun menara pandang untuk kepentingan pariwisata dan berujung membuka polemik dengan otoritas pengelola Sangiran.”

Selain itu pengembangan Kawasan Sangiran masih dilakukan oleh masing-masing daerah dalam memberikan pelayanan kepada pengunjung. Masalah lain yang muncul dilapangan adalah infrastruktur yang kurang memadai. Ditambah lagi dengan adanya penolakan pemerintah kabupaten terhadap Surat Keputusan Gubernur Nomor 430/197/2014 dan Penetapan Mendikbud Nomor 019/M/2015 tentang satuan ruang geografis Sangiran.

Penelitian terdahulu yang relevan dengan penelitian ini telah dilakukan Hardini (2017) menegaskan bahwa perlu segera dilakukan pengelolaan wisata secara terpadu oleh Kabupaten Sragen dan Kabupaten Karanganyar agar peran wisata cagar budaya berjalan maksimal. Kemudian penelitian yang dilakukan Putra (2014) menjelaskan bahwa kerjasama daerah belum termanfaatkan dengan baik, kreatifitas pemerintah

daerah dalam memanfaatkan mekanisme kerjasama daerah untuk mendukung pembangunan daerah belum nampak serta terhambat kemampuan unit kerja yang kurang maksimal. Selain itu, Pranata, Soeady, \& Hanafi (2015) melakukan penelitian kerjasama pemerintah Kota Malang dengan Kota Batu dan Kabupaten Malang dalam pengelolaan sumber daya air didukung dengan adanya kesamaan, komitmen bersama dan saling menguntungkan dan terhambat regulasi yang kurang jelas, database yang tidak mendukung serta kurangnya dukungan dari masyarakat.

Oleh karena itu, berdasarkan permasalahan yang telah dijelaskan, maka tujuan penelitian ini adalah:

a. Mengetahui jalinan kerjasama antar daerah dalam pengembangan pariwisata Kawasan Sangiran

b. Mengetahui faktor pendorong dan faktor penghambat kerjasama antar daerah dalam pengembangan pariwisata Kawasan Sangiran.

Penelitian ini juga diharapkan dapat memberikan masukan kepada pemerintah pusat maupun pemerintah daerah dalam melaksanakan kerjasama dalam pengembangan pariwisata Kawasan Sangiran.

\section{TINJAUAN PUSTAKA}

A. Kerjasama antar daerah

Pratikno (2007) dalam
Putranto (2013)
pengertian yang samg rapkan
kerjasama adalah hubungan dua
pihak atau lebih untuk mencapai
tujuan yang telah disepakati bersama.
kerjasama antar daerah dapat
didefinisikan sebagai hubungan antar
pemerintah mencakup semua
hubungan yang kompleks dan


interdependensi antara berbagai bidang pemerintahan antara pemerintah pusat, provinsi, dan lokal melalui persyaratan pelaporan program bantuan hibah, perencanaan dan proses anggaran dan komunikasi informal antar pejabat (Fox and Mayer dalam Irawanto, et.all, 2015).

Menurut Wright (1974) dalam (Irawanto et.al, 2015), ada 5 elemen kunci dalam pelaksanaan Intergovernmental Relations yaitu:

1. The roles of government

Fokus ini menekan pada IGR termasuk sebagai objek yang tepat untuk mempelajari semua permutasi dan kombinasi hubungan di antara unit-unit pemerintahan. Unit-unit pemerintahan terdiri dari national, states, counties, municipalities, special districts dan school districts

2. The interactions of public officials

Elemen kedua ini artinya tidak ada hubungan antara pemerintahan melainkan hanya ada hubungan antara pejabat dari unit pemerintahan yang berbeda. Interaksi diamati melalui empat sub-elemen, yaitu, sikap, kepercayaan, persepsi, dan preferensi dari personel yang terlibat.

3. Sustainability communication

Gagasan ketiga yang tersirat dalam IGR adalah bahwa relasi bukan satu kali, kejadian sesekali, diratifikasi secara formal dalam perjanjian atau secara kaku ditetapkan oleh undang-undang atau putusan pengadilan. Sebaliknya, IGR adalah pola kontak, pengetahuan, dan evaluasi pejabat pemerintah yang terus menerus dari hari ke hari. Perhatian utama adalah dengan informal maupun formal, praktik-praktik serta prinsipprinsip, dikejar dalam pola interjurisdikional yang kompetitif dan kooperatif.

4. The roles administrators

Hubungan antar pemerintah menekankan pada peran penting yang dimainkan oleh semua pejabat publik yang terlibat dalam kerja sama seperti pejabat yang terpilih dan administrator yang ditunjuk. Para administrator yang ditunjuk adalah pejabat publik yang ditunjuk baik dari otoritas publik dan otoritas dengan fungsi khusus / profesional. Sedangkan pejabat yang terpilih terdiri dari pejabat dari segi eksekutif, legislatif dan yudikatif.

5. Focus attentions on the policy

Fokus ini akan melihat seberapa jauh perhatian dari pemerintah terhadap kerja sama yang dilakukan dapat mempengaruhi kebijakan umum, terutama dalam hal kebijakan fiskal. Dalam hal ini, harus ada perhatian mendalam pada dampak pada anggaran lokal, terutama dari sub-elemen seperti masalah keuangan (kapasitas anggaran), dukungan politik, dan dampaknya pada bidang kebijakan lainnya.

B. Pengembangan pariwisata

Menurut Poerwadarminta dalam (Muhaidin, 2015) pengembangan adalah suatu strategi 
yang dipergunakan untuk memajukan, memperbaiki dan meningkatkan kondisi suatu objek menjadi lebih baik, maju, sempurna dan berguna. Sehingga objek tersebut dapat memberikan manfaat bagi masyarakat disekitar maupun bagi pemerintah daerah.

Suatu pengembangan pariwisata akan berjalan apabila terdapat komponen yang dipenuhi. Komponen pengembangan pariwisata tersebut menurut Cooper et. All (1995) dalam Muhaidin (2015) adalah sebagai berikut.

1. Atraksi dapat diartikan sebagai segala sesuatu yang terdapat di daerah wisata yang dapat menarik wisatawan untuk berkunjung ke suatu daerah.

2. Aksesibilitas dalam pariwisata berkenaan dengan tingkat kemudahan seseorang wisatawan mencapai suatu objek wisata.

3. Fasilitas dapat diartikan sebagai sarana dan prasarana yang disediakan oleh pengelola untuk kebutuhan wisatawan

4. Ancillary services berkaitan dengan organisasi kepariwisataan yang dibutuhkan untuk pelayanan wisata.

Kemudian dengan adanya otonomi daerah, dibutuhkan dukungan pemerintah daerah dalam pariwisata, menurut Pitana dan Gayatri dalam Simamora \& Sinaga (2016) peran pemerintah daerah dalam pariwisata adalah motivator, fasilitator, dinamisator.

\section{METODE PENELITIAN}

Penelitian ini dilakukan di Provinsi Jawa Tengah, Kabupaten Sragen dan Kabupaten Karanganyar. Penelitian ini menggunakan desain penelitian kualitatif deskriptif yang bertujuan untuk menggambarkan kondisi dan situasi kerjasama antar daerah dalam pengembangan pariwisata di Kawasan Sangiran. Data yang digunakan adalah data primer dan data sekunder. Teknik pemilihan informan dengan purposive sampling. Teknik pengumpulan data dengan menggunakan wawancara dengan birokrat-birokrat terkait dan dokumensi berupa foto, peraturan-peraturan, dan dokumen lain yang mendukung penelitian. Teknik analisis data menggunakan analisis model interaktif Miles dan Huberman yaitu dengan tahapan reduksi data, penyajian data dan penarikan kesimpulan.

\section{HASIL DAN PEMBAHASAN}

Kerjasama antar daerah dalam pengembangan pariwisata Kawasan Sangiran adalah melihat jalinan kerjasama antar daerah dengan menggunakan 5 elemen intergovernmental relations yaitu the role of governments, the interaction of public officials, sustainability communucations, the roles of administrator, focus on the policy serta menjelaskan faktor pendorong dan penghambat kerjasama antar daerah.

A. Kerjasama antar daerah dalam pengembangan pariwisata Kawasan Sangiran

Kawasan $\begin{array}{r}\text { Sangiran } \\ \text { merupakan salah satu warisan }\end{array}$
budaya nasional bahkan dunia yang
letaknya berada di perbatasan dua
daerah yaitu Kawasan Sragen dan
Kabupaten Karanganyar. Oleh
karena itu mengingat status sangiran
sebagai World Heritage yang terletak


di daerah maka dalam mengembangkan pariwisata di Kawasan Sangiran tidak bisa hanya dilakukan satu pihak saja, namun perlu adanya jalinan kerjasama antara daerah yang terlibat yaitu pemerintah pusat dan pemerintah daerah. Kerjasama antar daerah dalam pengembangan pariwisata Kawasan Sangiran sudah dilakukan sejak tahun 2009 dengan penandatanganan MoU antara Kementrian Kebudayaan dan Pariwisata, Pemerintah Provinsi Jawa Tengah, Pemerintah Kabupaten Sragen dan Pemerintah Kabupaten Karangnyar. MoU tertuang dalam Kesepakatan Bersama Kebudayaan dan Pariwisata, Pemerintah Provinsi Jawa Tengah, Pemerintah Kabupaten Sragen dan Pemerintah Kabupaten Karangnyar Nomor KB.09/KS001/MPK/2009; Nomor 18/2009; Nomor 556/897-34/2009; Nomor 556/2706.17 tanggal 6 April 2009 tentang perlindungan, pengembangan dan pemanfaatan situs sangiran sebagai Warisan Budaya Dunia.

Kerjasama berlanjut pada tahun 2014 dengan penandatangan Kesepakatan Bersama Menteri Pendidikan dan Kebudayaan Republik Indonesia, Gubernur Jawa Tengah, Bupati Sragen, Bupati Karanganyar Nomor 105620/MPK.F/CB 2014; Nomor 32/2014; Nomor 019.6/213.A/001/2014; Nomor 100/ 59 Tahun 2014 tentang perlindungan, pengembangan dan pemanfaatan Kawasan Sangiran sebagai warisan budaya dunia. Kemudian dalam kerjasama tersebut yang menjadi ruang lingkup kerjasama adalah dokumen kelengkapan administrasi, pembiayaan, pengadaan tanah, pembangunan dan pengembangan Kawasan Sangiran, perlindungan dan pengembangan potensi situs, pengelolaan dan pemanfaatan, bagi hasil pendapatan, pemberdayaan masyarakat.

B. Pelaksanaan kerjasama antar daerah dalam pengembangan pariwisata Kawasan Sangiran

Untuk melihat bagaimana jalinan kerjasama antar daerah tersebut dapat dilihat dari bagaimana intergovernmental relations itu berjalan. Hal itu dapat dilihat dengan 5 elemen kunci intergovernmental relations yang diungkapkan oleh Wright (1974) dalam (Irawanto et.al, 2015). Berikut penjelasannya.

1. The roles of government

Aspek ini menekankan ada hubungan antar unit pemerintahan. Pengembangan pariwisata di Kawasan Sangiran melibatkan 4 pihak yaitu pemerintah pusat, pemerintah Provinsi Jawa Tengah, pemerintah Kabupaten Sragen dan pemerintah Kabupaten Karanganyar. Kerjasama ini, setiap pihak mempunyai peran masing-masing. Peran pemerintah pusat dalam kaitannya pengembangan pariwisata Kawasan Sangiran adalah menetapkan Sangiran sebagai Kawasan Strategis Kepariwisataan Nasional (KSPN) di Jawa Tengah. Selain itu, pemerintah pusat melakukan pelestarian cagar budaya Kawasan Sangiran. Pemerintah 
pusat juga berperan untuk membangun museum dan merawat koleksi museum. Saat ini pemerintah pusat telah membangun 4 museum baru yaitu Bukuran, Manyarejo, Ngebung dan Dayu.

Peran pemerintah provinsi dilakukan dengan melakukan pemberdayaan masyarakat di Kawasan Sangiran dengan kegiatan pelatihan gejug lesung dan pelatihan pemandu wisata. Peran lain yang dilakukan pemerintah provinsi adalah dengan melakukan promosi pariwisata. Selain itu, pemerintah Provinsi Jawa Tengah menyediakan sarana dan prasarana pariwisata berupa tempat parkir khususnya berada di Museum Sangiran di Kabupaten Sragen. Pemerintah provinsi juga membangun infrastruktur untuk menunjang kegiatan pariwisata. Infrastruktur merupakan salah satu pendukung akses menuju tempat wisata. Dalam pengembangan pariwisata Kawasan Sangiran ini, Pemerintah Provinsi Jawa Tengah turut serta membangun infrastruktur seperti jalan dan jembatan.

Pemeritah kabupaten berkewajiban menyediakan lahan untuk pembangunan museum. Pemerintah kabupaten juga membangun infrastruktur berupa jalan penghubung antar klaster. Selain itu pemerintah kabupaten menyediakan sarana dan prasarana pariwisata. Hal itu diwujudkan pemeritah kabupaten Sragen dengan menyediakan loket dan petugas loket di Museum Sangiran Klaster Krikilan dan pemerintah kabupaten Karanganyar yang menyediakan loket, petugas loket dan tempat parkir dan Museum Klaster Dayu. Pemerintah kabupaten dalam kerjasama ini telah melakukan pemberdayaan kepada masyarakat dengan memberikan pelatihan-pelatihan kepada masyarakat.

2. The interaction of public officials

Interaksi pejabat publik dalam kaitannya dengan kerja sama antar daerah penting karena akan menentukan keberlanjutan kerja sama. Interaksi tersebut dilihat dari empat sub elemen yaitu perilaku, kepercayaan, persepsi dan preferensi dari aparatur yang terlibat. Berikut ini gambaran mengenai masing-masing sub elemen tersebut.

a. Perilaku

Aspek ini menunjukkan sikap pejabat dari masingmasing pihak yang terlibat kerjasama. Sikap pejabat dari tingkat pemerintah pusat, provinsi dan kabupaten dalam kerjasama ini ditunjukkan dengan mengijinkan pembangunan yang bisa merusak kelestarian kawasan Sangiran 
b. Kepercayaan

Kepercayaan merupakan aspek penting dalam menjalin kerjasama. Kerjasama ini dijalin dengan adanya rasa saling percaya antar pihak yang terlibat. Mulai dari tingkat pemerintah pusat, provinsi dan kabupaten saling percaya. Hal itu nampak dari pertanggungjawaban masing-masing pihak dalam menjalankan kewajibannya.

c. Persepsi

Aspek persepsi ini adalah melihat pemahaman masing-masing pihak tentang arti pentingnya kerjasama antar daerah dalam pengembangan pariwisata Kawasan Sangiran. Pemerintah pusat memandang bahwa Kawasan Sangiran merupakan cagar budaya yang letaknya berada di kabupaten sehingga dibutuhkan kerjasama antara pemerintah pusat dan daerah dalam pengembangan dan pengelolaannya. Selain itu, pengembangan pariwisata Kawasan Sangiran tidak bisa dibatasi oleh batas administrasi. Namun, pengembangan pariwisata Kawasan Sangiran membutuhkan kerjasama antar daerah.

d. Prefensi

Aspek preferensi menunjukkan kecenderungan masing- masing pihak yang terlibat kerjasama. Preferensi pemerintah pusat, provinsi dan kabupaten dalam pengembangan pariwisata Kawasan Sangiran adalah tetap menjaga kelestarian sebagai cagar budaya.

3. Sustainability communucations

Komunikasi antar pejabat daerah dalam kerjasama adalah sangat penting. Interaksi yang dilakukan antar para pejabat daerah secara teratur menunjukkan terjadinya komunikasi yang berlanjut. Apabila dilihat dari frekuensi komunikasi, kerjasama antar daerah pengembangan pariwisata Kawasan Sangiran telah dilakukan komunikasi rutin dengan adanya pertemuan melalui penjadwalan tertentu yang dilakukan oleh Balai Pelestarian Situs Manusia Purba Sangiran. Namun, frekuensi pelaksanaanya masih jarang dilakukan, yaitu dalam kurun waktu satu tahun hanya dilakukan 2 kali. Pertemuan dilakukan dengan kegiatan seperti survey, observasi langsung dilapangan dan FGD. Sedangkan hubungan kerja yang dijalin secara formal antar pihak yang terlibat diwujudkan dalam Memorandum of Understanding $(\mathrm{MoU})$ tentang perlindungan, pengembangan dan pemanfaatan Kawasan Sangiran sebagai warisan budaya dunia dan penandatanganan beberapa perjanjian kerjasama. Pola kumulatif yang terbentuk antar 
pemerintah pusat, pemerintah provinsi Jawa Tengah, pemerintah kabupaten Sragen dan Karanganyar adalah adanya pengelolaan yang dilakukan secara terpadu. Dimana setiap hubungan itu terjadi koordinasi antar pihak yang terlibat.

4. The roles of administrator

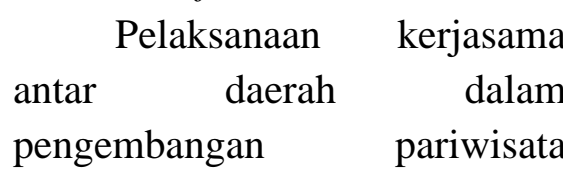
kawasan sangiran tidak terlepas dari peran pejabat eksekitif dan legislatif. Peran pejabat eksekutif baik tingkat pusat, provinsi maupun daerah adalah sebagai aktor kunci pelaksanaan kerjasama. Hal itu nampak pada lembaga eksekutif yang telah memberikan amanat kepada kepala dinas untuk melakukan kerjasama sehingga kerjasama tersebut bisa berlanjut. Sedangkan peran legislatif terkait dengan anggaran yang digunakan dalam melaksanakan kerjasama. Hal itu dikarenakan fungsi penganggaran berada ditangan legislatif sehingga anggaran akibat kerjasama ini harus mendapat persetujuan legislatif.

Pelaksanaan kerjasama ini, baik ditingkat pemerintah pusat, pemerintah provinsi dan pemerintah kabupaten sudah ada kejelasan siapa melakukan apa dan siapa yang mengendalikan pelaksanaan kerjasama pengembangan pariwisata Kawasan Sangiran. Pada tingkat pemerintah pusat pelaksanaan kerjasama ditangani oleh
Kementrian Pendidikan dan Kebudayaan Directoral Jenderal Kebudayaan yang pelaksanaan teknisnya dilakukan oleh BPSMP Sangiran. Pada tingkat pemerintah provinsi pelaksanaan kerjasama ditangani oleh Dinas Pariwisata Provinsi Jawa Tengah. Sedangkan pada tingkat kabupaten, pelaksanaan kerjasama ditangani oleh Dinas Pemuda Olahraga dan Pariwisata Kabupaten Sragen dan Dinas Pariwisata Pemuda dan Olahraga Kabupaten Karanganyar.

5. Focus on the policy

Setiap program dan kegiatan untuk mengembangkan pariwisata Kawasan Sangiran bersumber dari masing-masing pihak yang terlibat. Dalam pelaksanaan kerjasama, setiap pihak tidak melakukan alokasi anggaran yang dikhususkan untuk kerjasama pengembangan pariwisata kawasan sangiran. Namun, anggaran tersebut dialokasikan sesuai dengan kewenangannya dalam mengembangkan pariwisata Kawasan Sangiran.

$$
\text { Aspek dampaknya }
$$
terhadap kebijakan lain yaitu melihat sejauh mana kebijakan umum ditindak lanjuti secara operasional. Dalam kerjasama ini, pemerintah pusat telah menetapkan Sangiran sebagai Kawasan Strategis Kepariwisataan Nasional, membuat rencana induk pelestarian dan pengembangan (Master Plan) dan Detail Enginering Design Pelestarian 
Situs Sangiran. Salah satu rencana pelestarian dan pengembangan yang dilakukan adalah pembangunan museum baru. Pelestarian dan pengembangan dengan membangun museum tersebut ditindak lanjuti pemerintah daerah dengan melakukan pembebasan lahan. pemerintah daerah mengambil kebijakan pengalokasian dana pembebasan lahan.

C. Faktor pendorong dan faktor penghambat

1. Faktor pendorong

Pertama, adanya kesamaan pemikiran adanya kesamaan pemikiran bahwa Kawasan Sangiran merupakan salah satu cagar budaya yang telah diakui oleh dunia yang perlu untuk di jaga kelestariaanya.

Kedua, keuntungan ekonomi yang diperoleh. Kawasan Sangiran memiliki potensi wisata yang tinggi. Potensi wisata yang tinggi apabila di kembangkan secara terpadu akan memberikan keuntungan ekonomis kepada pemerintah dan masyarakat sekitar. Keuntungan itu berupa peningkatan Pendapatan Asli Daerah.

Ketiga, dukungan pemimpin daerah merupakan faktor pendorong yang penting dalam keberlangsungan kerjasama. Dukungan pemimpin kabupaten bisa dilihat dari kemauan untuk terus merajut kerjasama untuk mengembangkan Kawasan Sangiran.

2. Faktor penghambat

Kerjasama ini, pemerintah daerah dalam melaksanakan kewenangnnya untuk mengembangkan pariwisata kawasan sangiran terhambat dengan anggaran yang terbatas. Keterbatasan dana dialami oleh pemerintah daerah. Dana yang dimiliki hanya cukup untuk melakukan pembiayaan kegiatan pemeliharaan dan perawatan obyek wisata.

\section{SIMPULAN}

Kerjasama antar daerah dalam pengembangan pariwisata Kawasan Sangiran dapat disimpulkan bahwa hubungan pemerintahan dilakukan dengan adanya pembagian peran masingmasing pihak. Interaksi antar pejabat publik terlihat adanya kesamaan dalam perilaku, kepercayaan, persepsi dan preferansi. Berkenaan dengan komunikasi berkelanjutan yang dijalin melalui ada rapat koordinasi dan perjanjian kerjasama yang terus diperbarui. Keberlangsungan kerjasama tidak terlepas dari peran pejabat eksekutif sebagai aktor kunci, legislatif menjalankan fungsi penganggaran dan administrator pelaksana yang sudah jelas baik tingkat pusat, provinsi maupun kabupaten. Sedangkan dalam fokus kebijakan, anggaran kerjasama pengembangan pariwisata ditanggung oleh pihak yang terlibat dan kebijakan pemerintah pusat ditindak lanjuti oleh pemerintah daerah.

Faktor yang mendorong keberhasilan kerjasama ini adalah 
kesamaan pemikiran antar pihak, adanya keuntungan ekonomi dan dukungan pemimpin daerah. Sedangkan faktor penghambatnya adalah adanya perbedaan keterbatasan dana.

Berdasarkan hasil temuan-temuan penelitian, maka rekomendasi yang dapat diberikan untuk keberhasilan kerjasama pengembangan pariwisata Kawasan Sangiran yaitu menambah peran pemerintah daerah sebagai dinamisator dalam kerjasama pengembangan pariwisata Kawasan Sangiran, penggunaan alokasi dana desa bagi desa yang masuk Kawasan Sangiran untuk program pengembangan pariwisata Kawasan Sangiran dan pemerintah daerah bersama masyarakat memanfaatkan potensi budaya sebagai atraksi wisata.

\section{DAFTAR PUSTAKA}

Hardini, Vemi Asa. 2017. “Tingkat Kesesuaian Peran Komponen Wisata Kawasan Sangiran Sebagai Wisata Cagar Budaya”. Skripsi, Universitas Sebelas Maret Surakarta

Irawanto, et.al. 2015. “Intergovernmental Relations and Dilema of the Cooperation". Journal of Basic Applied Scientific Research Volume 5(8): 76-85. Diperoleh pada 12 November 2017,jam 19.45 WIB dari www.textroad.com

Kesepakatan Bersama Kebudayaan dan Pariwisata, Pemerintah Provinsi Jawa Tengah, Pemerintah Kabupaten Sragen dan Pemerintah Kabupaten Karangnyar Nomor KB.09/KS001/MPK/2009; Nomor 18/2009; Nomor 556/897-34/2009; Nomor 556/2706.17 tanggal 6 April 2009 tentang perlindungan, pengembangan dan pemanfaatan situs sangiran sebagai Warisan Budaya Dunia.

Kesepakatan Bersama Menteri Pendidikan dan Kebudayaan Republik Indonesia, Gubernur Jawa Tengah, Bupati Sragen, Bupati Karanganyar Nomor 105620/MPK.F/CB 2014; Nomor 32/2014; Nomor 019.6/213.A/001/2014; Nomor 100/ 59 Tahun 2014 tentang perlindungan, pengembangan dan pemanfaatan Kawasan Sangiran sebagai warisan budaya dunia.

Muhaidin.2015. "Kerjasama Antar Daerah dalam Pengembangan Pariwisata Teluk Saleh, Pulau Moyo dan Gunung Tambora (SAMOTA) tahun 2015”. Prosiding Konferensi Nasional ke-3. Diperoleh pada 12 Mei 2017, jam 13.40 WIB, dari http://respository.umy.ac.id

Nurhan, Kenedi \& Sulistyanto, Bambang. 2009. Situs Sangiran di Tengah Konflik Kepentingan. Diperoleh pada 13 Mei 2018, jam 20.56 WIB, dari https://juliantokompas-blogspot.com

Pranata, Andhi.,Saleh, Muhammad Soeadi \& Hanafi,Imam. 2015. "Kerjasama antar Pemerintah Daerah dalam Pengelolaan Sumber Daya Air (Studi pada Kerjasama Kota Malang dengan Kota Batu dan Kota Malang dengan Kabupaten Malang dalam Pengelolaan Sumber Daya Air)”. Jurnal Administrasi Publik Volume 
3(10):1787-1791. Diperoleh pada 12 Januari 2018, jam 17.46 WIB, dari http://media.neliti.com

Putra, Imam Radianto Anwar Setya. 2014. "Identifikasi Pelaksanaan Kerjasama Antar Daerah” Juranl Bina Praja Volume 6(2): 157-166. Diperoleh pada 18 Februari 2018, jam 10.56 WIB dari www.binaprajajournal.com

Putranto, Adhitya Eka. 2013. "Peran BKAD SUBOSUKAWONOSRATEN dalam Kerjasama antar Daerah”. Jurnal Pembangunan Wilayah dan Kota Volume 9(2): 111-121. Diperoleh pada 9 Desember 2017, jam 13.55,dari http://ejournal.undip.ac.id

Simamora, Rotua Kristin \& Sinaga, Rudi Salam. 2016. "Peran Pemerintah Daerah dalam Pengembangan Pariwisata Alam dan Budaya di Kabupaten Tapanuli Utara”. Jurnal Ilmu Pemerintahan dan Sosial Politik UMA Volume 4(1): 79-96. Diperoleh pada 17 Februari 2018, jam 16.49 WIB dari www.ojs.uma.ac.id

Suwantoro, Gamal. 2004. Dasar-Dasar Pariwisata. Yogyakarta: Andi

Wahyudi. 2010. "Kajian Kerjasama antar Daerah dalam Pengembangan dan Pengelolaan Kawasan Wisata Dataran Tinggi Dieng”. Thesis, Universitas Diponegoro Semarang 